\title{
PENDAMPINGAN IMPLEMENTASI MEDIA PEMBELAJARAN INOVATIF PADA SEKOLAH DASAR DI KECAMATAN PENEBEL
}

\author{
oleh, \\ Ni Nyoman Parwati, I Nengah Suparta' I Gusti Putu Suharta \\ Fakultas Matematika dan IPA \\ Universitas Pendidikan Ganesha
}

\begin{abstract}
ABSTRAK
Tujuan dari kegiatan Pengabdian pada Masyarakat (P2M) ini adalah Meningkatkan pengetahuan dan keterampilan para guru dalam mengimplementasikan media pembelajaran inovatif pada sekolah dasar di Kecamatan Penebel. Kegiatan P2M ini melibatkan 50 orang guru SD dan Kepala sekolah di Kecamatan Penebel yang dilaksanakan dalam bentuk pelatihan. Dari 50 orang guru yang ikut pelatihan, dipilih 3 orang yang didampingi dalam mengimplementasikan media inovatif pada kelas dan sekolah masing-masing. Pelaksanaan kegiatannya, sebagai berikut: (1) Melaksanakan pelatihan tentang cara mengimplementasikan media pembelajaran matematika inovatif dalam kegiatan pembelajaran selama satu hari. (2) Membimbing guru dalam mengimplementasikan media pembelajaran inovatif dalam kelas yang sesungguhnya selama dua bulan. (3) Melakukan penilaian terhadap kemampuan guru dalam menyusun RPP dan mengimplementasikan media pembelajaran inovatif dalam kelas. Hasil yang diperoleh dari seluruh kegiatan P2M ini adalah Terbentuk 7 kelompok kerja guru (KKG) dengan masing-masing anggota sebanyak 4 sampai 9 orang, berdasarkan distribusi lokasi sekolah. Rata-rata kemampuan mengajar guru menggunakan media inovatif, berkualitas "baik". RPP yang disusun guru, berkualitas "baik". Rata-rata hasil belajar matematika siswa mengalami peningkatan dari 6,2 sebelum pelaksanaan pembelajaran berbantuan media menjadi 7,4 setelah pelaksanaan pembelajaran berbantuan media. Berdasarkan hasil yang telah dicapai, para guru SD agar senantiasa berupaya secara terus menerus mengembangkan kemampuan profesionalisme guru melalui kegiatan KKG, sehingga masalah-masalah yang dihadapi dalam pelaksanaan pembelajaran di kelas masing-masing dapat dicarikan solusinya secara bersama-sama
\end{abstract}

Kata-kata kunci: media pembelajaran inovatif, pendampingan.

\begin{abstract}
The purpose of the activity at the Dedication to Community (P2M) is improve the knowledge and skills of teachers in implementing innovative learning media in elementary school in district Penebel. This activity involves 50 elementary teachers and school heads in district Penebel implemented in the form of training. From 50 peoples who took training, choose 3 peoples who accompanied implements innovative media in respectively their class and schools. Implementation of activities, as follows: (1) training on how to implement innovative math learning media in a one-day. (2) To
\end{abstract}


mentoring teachers in implementing innovative learning media in real classes for two months. (3) Perform an assessment of the ability of teachers in RPP organize and implement innovative learning media in the classroom. The result from all activities $\mathrm{P} 2 \mathrm{M}$ are formed 7 teacher working group (KKG) to each member of 4 to 9 peoples, based on the distribution of school location. The average of teacher ability to use innovative learning media is quality of "good". Teachers compiled RPP is quality of "good". The average student math learning outcomes increased from 6.2 to 7.4 after the implementation of the learning media. Based on the results achieved, the elementary school teachers that are constantly working to continuously expand teachers' professional ability through activities $\mathrm{KKG}$, until the problems encountered in the implementation of learning in each class can be sought together solution.

Keywords: innovative learning media, mentoring.

\section{Pendahuluan}

Lokasi Kecamatan Penebel Kabupaten Tabanan, sekitar 80 km dari kota Singaraja, dengan medan yang cukup berat. Sekolah dasar yang ada di Kecamatan Penebel sebanyak 34 sekolah. Lokasi sekolah, sebagian besar terletak di daerah pedesaan sehingga kegiatan P2M di bidang pendidikan yang dilakukan oleh Universitas Pendidikan Ganesha sangat jarang sampai ke wilayah-wilayah tersebut. Lokasi-lokasi sekolah yang sebagian besar terletak pada daerah yang agak terpencil mengakibatkan para guru jarang terlibat dalam kegiatan-kegiatan ilmiah yang dilakukan oleh Perguruan Tinggi. Sebagai dampaknya pengetahuan dan pemahaman para guru di wilayah ini masih kurang terkait dengan desain pembelajaran yang salah satunya adalah pengembangan media pembelajaran ataupun inovasi-inovasi kegiatan pembelajaran lainnya. Informasi yang sama, juga diperoleh dari hasil wawancara yang dilakukan dengan beberapa guru SD dan kepala sekolah yang ada di Penebel.

Wawancara dengan tiga kepala sekolah yang dipilih secara acak di Kecamatan Penebel, diperoleh informasi bahwa para guru hampir tidak pernah menggunakan media pembelajaran inovatif karena medianya tidak ada dan kemampuan para guru untuk mengembangkannya juga kurang. Hal ini berdampak pada pelaksanaan kegiatan pembelajaran berlangsung dengan kurang bermakna dan cenderung bersifat hafalan semata. Sebagai muaranya adalah prestasi belajar siswa masih rendah atau belum tercapai secara optimal. Berdasarkan wawancara tersebut juga diperoleh informasi, para kepala sekolah sangat mengharapkan kegiatan P2M seperti ini agar bisa dilakukan secara berkesinambungan karena menurut mereka para guru di daerah ini sangat 
memerlukan penyegaran-penyegaran materi, baik terkait dengan konsep materi pelajaran maupun kemampuan pedagogiknya.

SD yang ada di Kecamatan Penebel sebanyak 34 dengan guru sebanyak 290 orang. Mempertimbangkan jumlah guru yang cukup banyak, dengan pemahaman yang masih kurang dalam desain pembelajaran, khususnya dalam pengembangan media pembelajaran inovatif maka dipandang perlu untuk mengadakan kegiatan P2M yang melibatkan para guru di daerah ini. Kegiatan ini dimaksudkan untuk memotivasi para guru dan siswa di sekolah tersebut agar mau melaksanakan kegiatan belajar dan mengajar secara lebih efektif dan inovatif. Di samping itu, agar para guru khususnya dalam mengajar mau melakukan inovasi-inovasi sebagai bagian dari tugas profesionalismenya. Media pembelajaran yang dikembangkan nantinya, diharapkan mampu memfasilitasi siswa untuk belajar dengan lebih mudah sehingga proses dan hasil belajar dapat dicapai dengan lebih berkualitas, sesuai dengan pendapat Parwati, dkk., 2007; 2008; dan Reigeluth, 1999).

Beberapa masalah yang berhasil diidentifikasi yang terjadi pada sebagian besar sekolah dasar di kecamatan Penebel adalah sebagai berikut. (1) Pengetahuan dan keterampilan para guru tentang prosedur pengembangan media pembelajaran masih sangat kurang. (2) Pelibatan para guru dalam kegiatan ilmiah masih kurang. (3) Kinerja para guru dalam membuat media pembelajaran inovatif, masih kurang. (4) Penggunaan media pembelajaran inovatif di kelas sangat kurang. Berdasarkan hal ini secara umum masalah yang dapat dirumuskan adalah " Perlunya meningkatkan pengetahuan dan keterampilan para guru dalam mengimplementasikan media pembelajaran pada Sekolah Dasar di kecamatan Penebel".

\section{Metode Pelaksanaan Pengabdian}

P2M ini dilaksanakan dalam bentuk pendampingan yang terdiri dari dua tahap yaitu: tahap pelatihan (kegiatan peer teaching) dan tahap kedua, pendampingan implementasi media pembelajaran inovatif di sekolah masing-masing. Kegiatan yang dilakukan pada tahap pelatihan implementasi media pembelajaran (praktek peer teaching) adalah (a) merencanakan tempat pelatihan pada satu lokasi yang disepakati 
bersama para guru yang dijadikan khalayak sasaran; (b) melaksanakan kegiatan pelatihan selama satu hari.

Kegiatan pada tahap pendampingan implementasi media pembelajaran inovatif di sekolah masing-masing, dilakukan dengan (a) membimbing guru dalam mengimplementasikan media pembelajaran di sekolah masing-masing selama dua bulan; (b) melakukan penilaian terhadap rencana pelaksanaan pembelajaran (RPP) dan pelaksanaan pembelajaran menggunakan media pembelajaran inovatif yang dihasilkan oleh para guru.

Evaluasi dilakukan terkait dengan kemampuan guru dalam mengimplementasikan media pembelajaran dalam kegiatan pembelajaran di kelas masing-masing. Sebagai instrumen evaluasi adalah lembar penilaian berupa alat penilaian kemampuan mengajar guru (APKG) termasuk rencana pelaksanaan pembelajaran (RPP) yang dibuat oleh guru. penilaian terhadap kualitas RPP dan kemampuan mengajar guru dilakukan menggunakan rubrik penskoran dengan skala Likert dengan rentangan skor 1 sampai $5 .$. Analisis data dilakukan secara deskriptif.

\section{Hasil Dan Pembahasan}

Hasil yang dicapai melalui kegiatan P2M ini dituangkan dalam bentuk hasil kegiatan pada setiap tahap pelaksanaan, yaitu tahap: perencanaan, tindakan, observasi dan evaluasi, dan refleksi, sebagai berikut. Tahap perencanaan, kegiatan-kegiatan yang dilakukan pada tahap perencanaan adalah sebagai berikut. (1) Pembentukan dan pembekalan kelompok kerja guru (KKG) matematika, Pelaksanaan tahap ini didahului dengan mengundang tim pelaksana untuk mengadakan pertemuan persiapan pelaksanaan dengan melibatkan LPM Undiksha. Kegiatan ini dilakukan pada bulan April sampai dengan bulan Mei 2013. Tim pelaksana diberikan pembekalan mengenai maksud, tujuan, rancangan mekanisme program P2M, dan beberapa hal teknis berkaitan dengan metode/teknik pelaksanaan. (2) Sosialisasi program P2M pada dua sekolah mitra (khalayak sasaran), sosialisasi dilakukan pada bulan Juni 2013 dalam bentuk rapat koordinasi dengan mengundang semua guru pada sekolah mitra yaitu SD 1 Penebel dan SD 3 Mengesta, Kepala Sekolah, dan Kepala UPTD Dinas Pendidikan Pemuda Dan Olah Raga Kecamatan Penebel, berkenaan dengan program yang 
dilaksanakan. Kegiatan sosialisasi dilakukan oleh Tim Pelaksana didampingi oleh LPM Undiksha. (3) Penyusunan program pelatihan, berdasarkan hasil identifikasi, hasil analisis permasalahan yang ada, hasil analisis kebutuhan, dan hasil analisis potensi sekolah, selanjutnya disusun program pelatihan. Pelaksanaan pelatihan dilakukan selama 1 hari tatap muka, dengan mengundang 50 orang guru SD yang ada di kecamatan Penebel. Pelatihan yang diberikan berupa penyusunan RPP berdasarkan kurikulum 2013 dan prosedur pembuatan media pembelajaran matematika serta cara mengimplementasikannya dalam kegiatan pembelajaran.

Tahap pelaksanaan tindakan, tindakan dalam kegiatan ini berupa implementasi Program. Kegiatan-kegiatan yang dilakukan dalam implementasi program adalah sebagai berikut. (a) Pembentukan kelompok-kelompok kerja guru, kegiatan ini dilaksanakan pada bulan September 2013. Berdasarkan distribusi lokasi sekolah, dibentuk 7 kelompok kerja guru dengan masing-masing anggota sebanyak 4 sampai 9 orang. (b) Meningkatkan pengetahuan dan keterampilan para guru tentang implementasi media pembelajaran matematika di kelas. Kegiatan ini dilakukan melalui pemberian pelatihan, pelaksanaan dilakukan pada tanggal 21 September 2013 bertempat di SD 1 Penebel. (c) pendampingan penggunaan media pembelajaran dalam pembelajaran matematika di kelas. Kegiatan ini dilakukan sampai akhir bulan Oktober.

Tahap Observasi dan Evaluasi, observasi dilakukan terhadap keterampilan guru dalam mengimplementasikan media pembelajaran matematika dalam kegiatan pembelajaran di kelas. Instrumen yang digunakan berupa catatan lapangan. Beberapa hal yang diobservasi adalah kendala-kendala, kekurangan-kekurangan, dan kelemahankelemahan yang muncul dalam proses pembelajaran berbantuan media inovatif di kelas. Kendala yang dihadapi sebagian besar guru dalam pelaksanaan pembelajaran matematika berbantuan media inovatif adalah penguasaan terhadap materi matematika masih kurang. Media yang digunakan masih secara klasikal, penggunaannya belum bisa dimanipulasi langsung oleh siswa. Namun, melalui penggunaan media yang dipandu oleh guru siswa telah berhasil belajar dengan cara yang lebih bermakna karena mereka dipandu untuk bisa menemukan konsep dari simulasi media tersebut, hal ini didukung oleh pendapat Smaldino, dkk., 2008 dan Undang-undang RI Nomor 20 tahun 2003 yang 
mengatakan bahwa dengan melaksanakan pembelajaran berbantuan media inovatif siswa akan belajar secara bermakna.

Evaluasi dilakukan terhadap kemampuan guru dalam mengimplementasikan media pembelajaran matematika dalam kegiatan pembelajaran di kelas. Instrumen yang digunakan adalah alat penilaian kemampuan guru (APKG) yang diadopsi dari APKG sertifikasi guru rayon 21 Undiksha tahun 2013. Evaluasi dilakukan pada tiga orang guru yang dipilih, yaitu masing-masing pada sekolah: SD 1 Penebel, SD 2 Penebel, dan SD 3 Mengesta. Hasil evaluasi adalah rata-rata kemampuan mengajar guru menggunakan media pembelajaran matematika yang telah dikembangkan berkualitas "baik" dan RPP yang disusun guru, berkualitas "baik". Rata-rata hasil belajar matematika siswa mengalami peningkatan dari 6,2 sebelum pelaksanaan pembelajaran berbantuan media menjadi 7,4 setelah pelaksanaan pembelajaran berbantuan media.

Tahap refleksi, refleksi dilakukan terhadap kegiatan yang telah dilaksanakan. Hal ini dilakukan semata-mata untuk mengetahui kekurangan-kekurangan atau kelebihankelebihan terhadap kegiatan-kegiatan yang telah dilakukan dalam rangka menetapkan rekomendasi terhadap keberlangsungan atau pengembangan kegiatan-kegiatan berikutnya. Hasil refleksi adalah perlu dilakukan suatu upaya untuk membantu meningkatkan penguasaan guru terhadap materi matematika SD. Perlu dilakukan pengembangan media yang memungkinkan untuk bisa dimanipulasi langsung oleh siswa secara mandiri.

Kegiatan P2M yang dilaksanakan pada guru-guru SD di Kecamatan penebel telah berlangsung dengan baik. Hal ini terlihat dari animo guru untuk mengikuti kegiatan pelatihan sangat tinggi, terbukti dengan kehadiran para guru untuk mengikuti kegiatan mencapai $100 \%$. Hal ini mengindikasikan bahwa para guru menyambut positif kegiatan yang telah dilakukan. Sesuai dengan harapan para sekolah, mereka sangat mengharapkan adanya kegitan-kegiatan yang sifatnya memberi penyegaran bagi para guru di daerah ini, baik terkait dengan pendalaman materi bidang studi ataupun terkait dengan metode mengajar, mengingat hampir $60 \%$ dari para guru sudah berumur di atas 40 tahun.

Kepala sekolah, kepala UPTD, dan pengawas, menyambut antusias terkait pelaksanaan kegiatan P2M ini. Pengawas yang hadir, berharap agar dilakukan kegiatan 
secara berkesinambungan dan disarankan untuk mengembangkan media yang disusun untuk materi-materi yang lain. Pengawas dan kepala UPTD juga berharap agar ada pembinaan dari perguruan tinggi di daerah ini untuk meteri olimpiade.

Dalam kegiatan pelatihan, para guru sangat antusias dalam mempraktekkan alat-alat peraga (media) yang telah disusun dalam kegiatan peer teaching. Banyak masukan yang diberikan, baik oleh para guru ataupun oleh tim pelaksana P2M terkait dengan pelaksanaan pembelajaran berbantuan media inovatif. Masukan yang diberikan oleh tim pelaksana P2M lebih banyak terkait dengan pendalaman materi bidang studi terkait dengan media yang dikembangkan, misalnya materi tentang pengertian simetri putar dan cara mengajarkannya menggunakan media. Sebanyak tujuh alat peraga yang sempat disimulasikan dan kemampuan mereka berkualitas cukup dan baik. Dari 50 orang guru yang mengikuti pelatihan dipilih 3 orang yang didampingi untuk melaksanakan pembelajaran matematika berbantuan media inovatif pada kelas dan sekolah di masingmasing.

Melalui kegiatan pendampingan, pelaksanaan pembelajaran berbantuan media inovatif dapat berlangsung dengan baik. RPP yang disusun disesuaikan dengan kurikulum 2013, dengan menyusun RPP tematik. RPP yang disusun berkualitas baik. Kemampuan guru yang dinilai menggunakan APKG, berkualitas baik. Rata-rata hasil belajar matematika siswa mengalami peningkatan dari sebelum pelaksanaan pembelajaran berbantuan media dengan setelah pelaksanaan pembelajaran berbantuan media.

Kendala-kendala yang dihadapi dalam pelaksanaan P2M ini adalah masalah waktu pelaksanaan sering terganggu dengan adanya hari-hari libur keagamaan dan kegiatankegiatan yang lain. Di samping itu masalah yang cukup mengganggu adalah keterlambatan pencairan dana, sehingga waktu pelaksanaan kegiatan menjadi mundur, tidak bisa berlangsung sesuai dengan rencana. Namun, semua kendala dan masalah yang muncul telah dicarikan solusinya, yaitu dengan melaksanakan kegiatan pelatihan pada hari sabtu dan lebih banyak kerja dalam kelompok kerja guru (KKG). Dengan demikian kegiatan P2M ini telah berlangsung dengan baik. 


\section{Penutup}

Berdasarkan hasil yang diperoleh dalam pelaksanaan kegiatan P2M ini, dapat disimpulkan bahwa telah terbentuk 7 kelompok kerja guru (KKG) dengan masingmasing anggota sebanyak 4 sampai 9 orang, berdasarkan distribusi lokasi sekolah. Rata-rata kemampuan mengajar guru menggunakan media pembelajaran matematika yang telah dikembangkan, berkualitas "baik" demikian juga dengan RPP yang disusun guru, berkualitas "baik". Setelah pelaksanaan pembelajaran berbantuan media, hasil belajar siswa mengalami peningkatan dari rata-rata 6,2 menjadi 7,4. Oleh karena itu, para guru dalam melaksanakan kegiatan pembelajaran khususnya untuk materi matematika, agar menggunakan media yang inovatif, karena siswa akan belajar dengan cara yang bermakna dan sesuai dengan perkembangan kognitif siswa SD. Disamping itu, para guru SD agar senantiasa berupaya secara terus menerus mengembangkan kemampuan profesionalisme guru melalui kegiatan KKG, agar masalah-masalah yang dihadapi dalam pelaksanaan pembelajaran di kelas masing-masing dapat dicarikan solusinya secara bersama-sama.

\section{DAFTAR PUSTAKA}

Parwati, N.N., Mariawan, I. M., \& Suarsana, I. M. 2007. Peningkatan Profesionalisme Guru Matematika Melalui Pelatihan Implementasi Model-model Pembelajaran Berbantuan Alat Peraga Bagi Guru-Guru Sekolah Dasar No 3 Mengesta. Laporan $P 2 M$. Tidak diterbitkan. Singaraja: Undiksha.

Parwati, N.N. \& Mariawan, I. M. 2008. Pelatihan Penelitian Tindakan Kelas untuk Guru-guru SD di Kabupaten Tabanan. Laporan P2M. Tidak diterbitkan. Singaraja: Undiksha.

Reigeluth, C. M. 1999. Instructioanl-design theories and models: A new paradigm of instructional theory. Volume II. New Jersey: Lawrence Erlbaum Associates, Publishers.

Smaldino, S.E. , Lowther, D.L. \& Russell, J.D. 2008. Instructional Media and Technology for Learning. $9^{\text {th }}$ Edition. Upper Saddle Rive NJ: Pearson Education, Inc.

Undang-undang RI Nomor 20 tahun 2003 tentang Sisem Pendidikan Nasional. 2003. (Online) tersedia dalam www.hukumonline.com. 